\title{
Dizziness, Physical Exercise, Falls, and Depression in Adults and the Elderly
}

\author{
Adriane Ribeiro Teixeira ${ }^{1}$ Mariane Heckmann Wender ${ }^{2}$ Andréa Kruger Gonçalves ${ }^{3}$ \\ Cíntia de La Rocha Freitas ${ }^{4}$ Ana Maria Pujol Vieira dos Santos ${ }^{5}$ Cristina Loureiro Chaves Soldera ${ }^{6}$
}

1 Department of Health and Human Communication, Universidade Federal do Rio Grande do Sul - UFRGS, Porto Alegre, RS, Brazil

2 Phonoaudiology Specialization Course: Emphasis on Aging, UFRGS, Porto Alegre, RS, Brazil

3 Department of Physical Education, UFRGS, Porto Alegre, RS, Brazil

${ }^{4}$ Universidade Federal de Santa Catarina, Florianópolis, SC, Brazil

5 Universidade Luterana do Brasil, Canoas, Rio Grande do Sul, Brazil

${ }^{6}$ Department of Phonoaudiology, Universidade Federal de Ciências da

Saúde de Porto Alegre, Porto Alegre, Rio Grande do Sul, Brazil
Address for correspondence Adriane Ribeiro Teixeira, Department of Health and Human Communication - Universidade Federal do Rio Grande do Sul, Rua Ramiro Barcelos, 2777 / 315 - Anexo I da Saúde da UFRGS, Porto Alegre, Rio Grande do Sul 90035003, Brazil (e-mail: adriane.teixeira@gmail.com).

Int Arch Otorhinolaryngol 2016;20:124-131.

\begin{abstract}
Keywords

- dizziness

- falls

- depression

- exercise

Introduction Dizziness is a symptom that can lead to falls, which, in turn, undermine onés independence and autonomy, leading to several comorbidities. The practice of physical exercise, however, can help prevent falls.

Objective The objective of this study is to confirm the association between physical exercise, dizziness, probability of falling, and depressive symptoms in a group of middleaged adults and seniors.

Methods The authors evaluated subjects based on history, the Geriatric Depression Scale, and functional reach test.

Results The sample consisted of 90 individuals with a mean age of $69.3 \pm 6.8$ years. The authors found that $37.8 \%$ had been practicing exercise, $33.7 \%$ had depressive symptoms, and their probability of falling was above average in the functional reach test.

Conclusion The results of this study indicated an association between dizziness, exercise practice and depressive symptoms, indicating that physical activity is a beneficial factor for the aging population.
\end{abstract}

\section{Introduction}

Population aging can be considered as the most evident and dynamic aspect of modern demography, influencing the economy and public health in a significant way. The world has experienced a modest increase in the population above 60 years of age over the last six decades - from $8 \%$ to $10 \%$. However, this growth has been an unprecedented world phenomenon. During the 1950's, there were 204 million elderly in the world. In 1998, this number more than doubled, totaling 579 million; in 2011, the figure reached was 893 million. ${ }^{1}$ Over the next four decades, experts expect this age group to grow to $22 \%$ of the world population, which would correspond to 2.4 billion of elderly by the middle of this century. $^{2}$

In this sense, many elders will likely face health problems inherent to aging, as well as challenges in maintaining their independence. However, the elderly can stay healthy and active in society in an independent and sustainable manner, ${ }^{3}$ and the work of professionals and researchers in the received

June 22, 2015

accepted

August 9, 2015

published online

November 6, 2015
DOI http://dx.doi.org/

$10.1055 / \mathrm{s}-0035-1566304$. ISSN 1809-9777.
Copyright $(2016$ by Thieme Publicações License terms

Ltda, Rio de Janeiro, Brazil

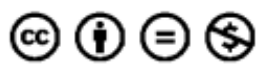


multidisciplinary health field that serve this group is fundamental in achieving this state. At the same time, it is essential that the government create and apply public policies that enable and sustain educational and awareness actions regarding people qualification and the fulfillment of the populationś basic needs.

As for the health of the elderly, changes in body balance (postural instability) have received much attention, as it is one of the symptoms that most affect their lives. Body balance is the result of a harmonious interaction among different systems in the human body: vestibular (inner ear - posterior labyrinth), visual, and somatic-sensorial (cutaneous, muscular, and articular receptors) systems. This interaction is accomplished through processes of the neural system, which organizes and executes a rapid response by means of the musculoskeletal system. ${ }^{4}$

The aging process is associated with a decrease in the ability to keep balance, especially in situations where responses of the balance keeping systems to unexpected disturbances during free moving and the avoidance of obstacles are necessary. Sensorial, motor, and adaptive balance components become vulnerable as degenerative, infectious, or damaging processes accumulate. Although small alterations in any of the systems that comprise balance keeping do not result in significant disturbances, the involvement of multiple components may lead to severe deficits in postural stability conservation. 5,6

The aging process may alter the dynamic posture keeping system. This condition is a contributing factor to falls among the elderly, albeit not the main cause. ${ }^{7}$ Impairment of the vestibular system is also believed to be a factor that leads the elderly to lose balance, through the aging process of this systeḿs organs. ${ }^{8}$

Alterations to postural stability are also followed by dizziness. This can be defined as any sensation of change in the body balance and can be rotational (vertigo) or nonrotational (unbalance, oscillation, vacillation, etc.). Both types may or may not be caused by specific vestibular system disturbances. ${ }^{9}$

The presence of dizziness may cause falls, which are associated to the main cause of death in the elderly group. Some authors also associate dizziness to partial or full inability to perform social, professional, family activities, in addition to causing physical and psychological damage, such as loss of self-confidence, depression, deficit in concentration, and performance, thus negatively interfering in the quality of life. ${ }^{10,11}$ However, it is still difficult to know if psychological problems pre-exist or are a result of vestibular complications. ${ }^{11}$

Balance disturbances and anxiety disorders share central neural circuits involving monoaminergic components, this being the reason why anxiety is often associated with balance alterations. These neural circuits concentrate in a parabrachial nucleus network (vestibular system and visceral information processing convergence point), also involving avoidance, anxiety, and fear symptoms. ${ }^{12}$ Physical insecurity triggered by dizziness and unbalance lead to psychological insecurity, irritability, loss of self-confidence, anxiety, depression or panic, a sense of being out of reality and depersonalization. ${ }^{13}$

Depression - which may be caused or made worse by body imbalance - is a common condition in seniors. Furthermore, it is associated to higher risk of morbidity and mortality, increase in health services usage, negligence in self-care, and higher risk of suicide. ${ }^{14}$ The main symptoms of depression are depressed mood and loss of interest or lack of pleasure in almost all activities, being characterized as a psychiatric syndrome. In the elderly, its manifestation occurs in a heterogeneous form regarding both the presentation aspects of its etiology and its treatment. ${ }^{15}$

Studies relate the involvement in physical activities with a better general health condition and lesser occurrence of depression and falls in the elderly. ${ }^{16,17}$ Physical activity is capable of improving mental and clinical conditions of depressed elderly. This is because physical activity stimulates cognitive, memory, and concentration functions, in addition to raising self-esteem, improving quality of life, ${ }^{18}$ and helping decrease scores indicative of anxiety and depression, ${ }^{19}$ favoring daily activities and promoting functional independence. $^{20}$ Furthermore, the physically active elderly show improvement of dizziness and vertigo symptoms, ${ }^{21-23}$ decreasing, as a result, the risk of falls and associated comorbidities.

Thus, the objective of this work is to verify the correlation between physical exercise, dizziness, probability of falls, and symptoms of depression in a group of middle-aged and elderly group.

\section{Methods}

This is a transversal and observational study with approval from the institutions Ethical Committee (record $n^{\circ}$ 216292011). The sample comprised adult and elderly individuals of both sexes who took part in university extension projects.

The inclusion factors for subjects were non-institutionalized elderly with no history of neurological or cognitive alterations, who voluntarily accepted to take part in the research and signed the Informed Consent Form (ICF).

Assessment procedures included a medical history prepared for this study; the abridged version of the Geriatric Depression Scale (GDS); and Anterior Functional Reach Test.

The medical history assessment included questions on individuals socio-demographic and health (age, gender, presence of diseases, treatment used), as well as questions about their practice of physical exercises (frequency, time of practice, type of physical exercise).

As for assessing the results of the geriatric depression scale, each answer indicating depression scored one point. Scores below five points indicated lack of depressive symptoms; 6 to 10 points indicated mild/moderate depressive symptoms; and 11 to 15 points meant severe depressive symptoms. $^{24}$

For the functional range test was initially placed a tape measure on the wall, parallel to the floor, at the height of the acromion of each individual. The following were instructed to 
position themselves parallel to the wall, without lean on to it, with the parallels and bare feet in a comfortable position. The upper limb was positioned with bent shoulders at $90^{\circ}$, extended elbows, wrists in a neutral, flat hand position. As a result, it was requested that incline forward as much as possible, hold for three seconds without taking the heels off the floor. Taking as the third metacarpal of the individual parameter was recorded in centimeters anterior displacement on the tape. Displacements smaller than $15.2 \mathrm{~cm}$ indicate the risk of falls four times higher compared to those who reached more than $25.4 \mathrm{~cm}$, or is highly likely to falls. Measures between 15.2 and $25.4 \mathrm{~cm}$ has an average probability of falls (twice as likely to fall than those who reach values greater than $25.4 \mathrm{~cm}$ ). Values greater than $25.4 \mathrm{~cm}$ indicate low probability of falls. ${ }^{25}$

The authors analyzed the data using descriptive statistics through measures of central tendency (mean and median) and variability (standard deviation and inner quartile ranges), as well as absolute and relative distribution ( $\mathrm{n}-\%)$. The symmetric continuous distribution was evaluated by the Kolmogorov-Smirnov test.

For the bivariate analysis between qualitative variables, the authors used the Pearson Qui-square test $\left(X^{2}\right)$ and continuity correction, which compares between observed (real) and expected frequencies. In contingency tables in which at least $25 \%$ of cell (quads) values presented expected frequency below five, they used Fisheŕs exact test. For continuous variables, when comparing two independent groups, the applied test was Students t-test or, its non-parametric equivalent, the Mann Whitney test. Multivariate analysis was accomplished through non-conditional Binary Logistic Regression, by employing regressive procedures to test the hypotheses of association between cognitive decline and co-variables defined by the bivariate analysis ( $p \leq 0.250$ ), by obtaining the adjusted Odds Ratio (OR). Data received statistical treatment via SPSS 17.0 software (Statistical Package for Social Sciences for Windows), adopting a significance level $(\alpha)$ of $5 \%$ for the decision-making criteria.

\section{Results}

The sample comprised of 90 individuals, aged 69.3 $( \pm 6.8)$ in average, with minimum age of 59 years and maximum age of 84 years. The majority of investigated individuals was in the age group between 65 and 74 years (38.9\%). The proportion of women was slightly higher (51.1\%). Physical exercise was practiced by $37.8 \%$ of the individuals (-Table 1 ).

The majority of individuals interviewed (65.8\%) did not show depressive symptoms. Regarding the Anterior Functional Reach test, the majority of evaluated individuals indeed showed low probability of fall occurrence, with an average score of $28.2 \mathrm{~cm}$ $(\mathrm{SD}=9.2$ ) points, varying from 0 to $44.5 \mathrm{~cm}$ (-Table 2).

In the analyses done on dizziness complaints, the authors verified a significant association with age group $(p<0.05)$, with the elderly aged 75 years or more presenting a higher probability of feeling dizziness, whereas the group aged between 65 and 74 years, this association was not verified (-Table $\mathbf{3}$ ).
Table 1 Absolute and relative distribution of the sample according to gender, age group, physical exercise, and dizziness; measures of central tendency and variability for age

\begin{tabular}{|c|c|c|}
\hline \multirow[t]{2}{*}{ Variables } & \multicolumn{2}{|c|}{ Distribution } \\
\hline & $\begin{array}{l}\text { Absolute } \\
\text { (n) }\end{array}$ & $\begin{array}{l}\text { Relative } \\
\text { (\%) }\end{array}$ \\
\hline \multicolumn{3}{|l|}{ Gender* } \\
\hline Male & 44 & 48.9 \\
\hline Female & 46 & 51.1 \\
\hline \multicolumn{3}{|l|}{ Age (years) } \\
\hline Average \pm standard deviation & \multicolumn{2}{|l|}{$69.3 \pm 6.8$} \\
\hline Minimum - maximum & \multicolumn{2}{|l|}{$59-84$} \\
\hline \multicolumn{3}{|l|}{ Age group (years)* } \\
\hline From 59 to 64 & 30 & 33.3 \\
\hline From 65 to 74 & 35 & 38.9 \\
\hline 75 years or more & 25 & 27.8 \\
\hline \multicolumn{3}{|c|}{ Practice of physical exercise* $¥ N R=5(2.5 \%)$} \\
\hline No & 56 & 62.2 \\
\hline Yes & 34 & 37.8 \\
\hline \multicolumn{3}{|l|}{ Time of physical exercise practice* } \\
\hline Less than 1 year & 5 & 14.7 \\
\hline Between 1 and 3 years & 10 & 29.4 \\
\hline Between 4 and 6 years & 8 & 23.5 \\
\hline Between 7 and 10 years & 5 & 14.7 \\
\hline More than 10 years & 6 & 17.6 \\
\hline \multicolumn{3}{|l|}{ Dizziness* } \\
\hline No & 54 & 60.0 \\
\hline Yes & 36 & 40.0 \\
\hline
\end{tabular}

*Results presented as $\mathrm{n}(\%)$, with percentage obtained as based on total valid cases; $¥$ : NR $=5(2.5 \%)$.

Moreover, it has been observed statistically significant association between the occurrence of dizziness and the presence of light/moderate depressive symptoms $(p<0.01)$, as well as between the occurrence of dizziness and the average probability of falls $(p<0.001)$.

In terms of the association between the occurrence of dizziness and the results of the Anterior Functional Reach test, the average in centimeters for the anterior reach $(25.3 \pm 5.4)$ of elderly with dizziness showed to be significantly less when compared with the average of the group without dizziness complaints $(30.1 \pm 10.6)(p<0.01)$.

When comparing the occurrence of dizziness with gender, age, practice of physical exercise, and time of practice, we identified an independent relation, evidencing that dizziness is unrelated to any of these factors in the studied group.

In the group of individuals that did not practice physical exercise, there was an association between the occurrence of dizziness and light/moderate depressive symptoms $(p<0.001)$. However, in the same analysis done with the group that practiced some physical activity, the association 
Table 2 Absolute and relative distribution of the sample for GDS scores and Anterior Functional Reach Test; measures of central tendency and variability for balance

\begin{tabular}{|c|c|c|}
\hline \multirow[t]{2}{*}{ Variables } & \multicolumn{2}{|c|}{ Distribution } \\
\hline & $\begin{array}{l}\text { Absolute } \\
\text { (n) }\end{array}$ & $\begin{array}{l}\text { Relative } \\
(\%)\end{array}$ \\
\hline \multicolumn{3}{|l|}{$\mathrm{GDS}^{*} \mathbb{N R}=11(12.2 \%)$} \\
\hline Absence of depression symptoms & 52 & 65.8 \\
\hline Light to moderate symptoms & 24 & 30.4 \\
\hline Serious symptoms & 3 & 3.3 \\
\hline \multicolumn{3}{|c|}{ Anterior Functional Reach Test (dislocation in cm) } \\
\hline Average \pm standard deviation & \multicolumn{2}{|c|}{$28.2 \pm 9.2$} \\
\hline Minimum - maximum & \multicolumn{2}{|l|}{$0.0-44.5$} \\
\hline \multicolumn{3}{|c|}{$\begin{array}{l}\text { Anterior Functional Reach Test - probability of falls }{ }^{*} \text { A } \\
N R=8(8.8 \%)\end{array}$} \\
\hline High & 4 & 4.9 \\
\hline Medium & 20 & 24.4 \\
\hline Low & 58 & 70.7 \\
\hline
\end{tabular}

*Results presented as $\mathrm{n}(\%)$, with percentage obtained as based on total valid cases, $\mathbb{W}: \mathrm{NR}=11(12.2 \%) ; \mathrm{AR}=8(8.8 \%)$.

between dizziness and depressive symptoms was not statistically significant $(\mathrm{p}>0.05)$ ( - Table 4$)$.

Another evaluation confirms the importance of physical exercise. Keeping the remaining variation factors not considered in the analysis (gender, age) constant, the group that practices physical exercise was less prone to dizziness and depressive symptoms (-Table 4).

We looked for and identified the variables that could respond in a more trustworthy form to the occurrence of dizziness. We performed the logistic regression analysis with an adjustment to minimize the number of explanatory variables employed and maximize model precision, through the Backward Model, to maximize the explanatory power of the study factor.

Through a model defined as saturated, we listed all variables with minimum significance level below 0.25 through bivariate analysis (-Table 3 ) as possible preceding factors for the presence of dizziness. They are the following: gender, age, age group, physical activity, GDS score, dislocation in the Anterior Functional Reach test, and balance. In this model, the variables for gender and age pointed out an independent relation to the occurrence of dizziness.

According to the adjusted logistic regression model, the following were significant predictive factors for the occurrence of dizziness: non-practice of physical exercise, classifications of light/moderate depressive symptoms, and dislocation in the Anterior Functional Reach test.

Results described in - Table $\mathbf{5}$ show that the elderly who do not practice physical exercise have 2.2 times higher risk of presenting dizziness than the group that practices some physical exercise. In relation to depressive symptoms, the significant risk of presenting dizziness occurred in the light/ moderate degree, indicating that the elderly included in this classification had 4.5 times more chance of presenting dizziness than the group with absence of depressive symptoms.

As the number of elderly with severe depressive symptoms was very low, the light/moderate and serious groups were merged, by classifying the answer for symptoms as presence or absence. Over this new variable, we once more calculated the risk of presence of depressive symptoms associated to dizziness, estimated at 2.1 times that of the group with absence of this symptom.

The results verified that the group with medium probability of falls as the result for the Anterior Functional Reach test had 4.0 times more chances of occurrence of dizziness than the group with low probability of falls.

When age was kept constant, results indicated that the non-practice of physical exercise, the presence of depressive symptoms, and the result of the Anterior Functional Reach test (indicating medium probability of falls) are factors associated to the occurrence of dizziness in the investigated sample.

\section{Discussion}

In the sample of this study, more than $60 \%$ of the individuals affirmed to not practice physical exercise, confirming other similar studies. The Ministry of Health of Brazil ${ }^{26}$ made a survey, and verified that $53.7 \%$ of elderly men and $58.3 \%$ of elderly women were inactive. Similar results were found in other study concerning the level of physical activity and its relationship with the environment (specifically, safety) with 1,656 elderly from Florianópolis. ${ }^{27}$ By using similar parameters, Pucci, Reis, Rech and Hallal ${ }^{28}$ classified the majority of the individuals of their study as insufficiently active in leisure or walking activities. In this study, 1,461 adults and elderly between 18 and 65 years of age were evaluated.

Current studies highlight the prevalence of dizziness reports among the elderly population. ${ }^{29-32}$ Approximately one in every five seniors currently presents dizziness or imbalance. $^{29}$ In our research, $40 \%$ of the elderly reported sensation of dizziness. This finding is very similar to other studies done in Brazil, in which the authors verified that the prevalence of dizziness in the elderly is substantial, having observed dizziness complaints from $45 \%$ of 391 elderly over 65 years of age interviewed. ${ }^{33}$

Another study interviewed 516 elderly people, and confirmed self-reported dizziness in $42 \%$ of them. ${ }^{31}$ Thus, dizziness is a common problem for the elderly population, ${ }^{11,34,35}$ as these individuals show a decrease in visual acuity during aging, and loss of balance due to the reduction of ciliated cells and vestibular neurons. This results in loss of functions from two important components responsible for keeping balance. ${ }^{36}$ Furthermore, with age, the central nervous system capabilities become impaired, affecting the processing of vestibular, visual, and proprioceptive signals responsible for maintenance of body balance. Age also reduces capacity of modifications of the adaptive reflexes, may be responsible for the occurrence of vertigo and/or dizziness in the geriatric population. ${ }^{35}$ 
Table 3 Absolute and relative distribution of the sample per gender, age group, physical activity; measures of central tendency and variability of age and time of physical activity with and without dizziness

\begin{tabular}{|c|c|c|c|}
\hline \multirow[t]{2}{*}{ Variables } & \multicolumn{2}{|l|}{ Dizziness } & \multirow[t]{2}{*}{$\mathrm{p}$ (value) } \\
\hline & No $(n=54)$ & Yes $(n=36)$ & \\
\hline \multicolumn{3}{|l|}{ Gender* } & \multirow[t]{3}{*}{$0.182 \rrbracket$} \\
\hline Male & $30(55.6)$ & $14(38.9)$ & \\
\hline Female & $24(44.4)$ & $22(61.1)$ & \\
\hline \multicolumn{3}{|l|}{ Age (years) } & \multirow[t]{3}{*}{$0.249 \S$} \\
\hline Average \pm standard deviation & $68.6 \pm 6.7$ & $70.3 \pm 6.9$ & \\
\hline Minimum - maximum & $59-84$ & $60-83$ & \\
\hline \multicolumn{3}{|l|}{ Age group (years)* } & \multirow[t]{4}{*}{$0.028 \phi^{*}$} \\
\hline From 59 to 64 & $18(33.3)$ & $12(33.3)$ & \\
\hline From 65 to 74 & $26(48.1)$ & $9(25.0)$ & \\
\hline 75 years or more & $10(18.5)$ & $15(41.7)$ & \\
\hline \multicolumn{3}{|l|}{ Physical exercise practice } & \multirow[t]{3}{*}{$0.069 \rrbracket$} \\
\hline No & $29(53.7)$ & $27(75.0)$ & \\
\hline Yes & $25(46.3)$ & $9(25.0)$ & \\
\hline \multicolumn{4}{|l|}{ GDS $*^{*}$} \\
\hline Absence of depressive symptoms & $39(81.3)$ & 13 (41.9) & \\
\hline Light to moderate symptoms & $8(16.7)$ & $16(51.6)$ & $0.001 £^{* *}$ \\
\hline Serious symptoms & $1(2.1)$ & $2(6.5)$ & \\
\hline \multicolumn{4}{|c|}{ Anterior Functional Reach Test (dislocation in cm) } \\
\hline Average \pm standard deviation & $30.1 \pm 10.6$ & $25.3 \pm 5.4$ & $0.008 \S^{* *}$ \\
\hline Minimum - maximum & $0.0-44.5$ & $16.0-40.0$ & \\
\hline \multicolumn{4}{|c|}{ Anterior Functional Reach Test (probability of falls)* } \\
\hline High & $4(8.0)$ & $0(0,0)$ & \\
\hline Medium & $5(10.0)$ & $15(46.9)$ & $<0.001 \mathrm{E}^{*}$ \\
\hline Low & $41(82.0)$ & $17(53.1)$ & \\
\hline
\end{tabular}

*Percentages obtained as based on total of each dizziness category; $\uparrow:$ Pearson Chi-square Test with continuity correction; §: t-Student test for independent groups; \$: Pearson Chi-square Test; £: Fisher’s Exact Test through Monte Carlo simulation; *Statistically significant test at 5\%;

${ }^{* *}$ Statistically significant test at $1 \%$.

Table 4 Absolute and relative distribution of the classification of depressive symptoms in relation to dizziness according to the practice of physical exercise in the studied sample

\begin{tabular}{|c|c|c|c|c|}
\hline \multirow[t]{4}{*}{ Depressive symptoms } & \multicolumn{4}{|c|}{ Physical exercise } \\
\hline & \multicolumn{2}{|l|}{ No $(n=55)$} & \multicolumn{2}{|l|}{ Yes $(n=24)$} \\
\hline & \multicolumn{4}{|l|}{ Dizziness } \\
\hline & No $(n=26)$ & Yes $(n=29)$ & No $(n=19)$ & Yes $(n=5)$ \\
\hline Absent & $22(75.9)$ & $9(34.6)$ & $17(89.5)$ & $4(80.0)$ \\
\hline Light/moderate & $6(20.7)$ & $16(61.5)$ & $2(10.5)$ & $0(0.0)$ \\
\hline Serious & $1(3.4)$ & $1(3.8)$ & $0(0.0)$ & $1(20.0)$ \\
\hline $\mathrm{p}$ (value)§ & \multicolumn{2}{|l|}{$0.002^{* *}$} & \multicolumn{2}{|l|}{0.243} \\
\hline
\end{tabular}

£: Fisher's Exact Test; ${ }^{* *}$ Statistically significant test at $1 \%$. 
Table 5 Estimation of parameters obtained from the adjusted Logistic Regression model (age) for the occurrence of dizziness, according to practice of physical exercise, depressive symptoms, and Anterior Functional Reach Test

\begin{tabular}{|c|c|c|c|c|c|c|}
\hline \multirow[t]{2}{*}{ Co-variables } & \multirow[t]{2}{*}{ Total sample $(n=79)$} & \multicolumn{2}{|c|}{$\begin{array}{l}\text { Occurrence of } \\
\text { dizziness }\end{array}$} & \multirow[t]{2}{*}{ OR } & \multirow[t]{2}{*}{ IC95\% ORE } & \multirow[t]{2}{*}{$\mathrm{p}$} \\
\hline & & $n$ & $\%$ & & & \\
\hline \multicolumn{7}{|c|}{ Practice of physical exercise } \\
\hline No & $56(62.2)$ & 27 & 48.2 & 2.205 & $1.122-6.447$ & 0.014 \\
\hline Yes & $34(37.8)$ & 9 & 26.5 & 1.000 & $\cdots$ & $\cdots$ \\
\hline \multicolumn{7}{|l|}{ Depressive symptoms* } \\
\hline Absence of depression & $52(65.8)$ & 13 & 41.9 & 1.000 & $\cdots$ & \\
\hline Light to moderate & $24(30.4)$ & 16 & 51.6 & 4.527 & $1.319-15.530$ & 0.016 \\
\hline Serious & $3(3.8)$ & 2 & 6.5 & 0.355 & $0.023-17.541$ & 0.874 \\
\hline \multicolumn{7}{|l|}{ Depressive symptoms* } \\
\hline Absence of depression & $52(65.8)$ & 13 & 41.9 & 1.000 & - - & \\
\hline Presence of depression & $27(34.1)$ & 18 & 66.7 & 2.118 & $1.234-4.657$ & 0.038 \\
\hline \multicolumn{7}{|c|}{ Anterior Functional Reach Test* - Probability of Falls } \\
\hline High & $4(4.9)$ & 0 & 0.0 & $\ldots$ & $\ldots$ & \\
\hline Medium & $20(24.4)$ & 15 & 75.0 & 4.075 & $1.127-14.740$ & 0.032 \\
\hline Low & $58(70.7)$ & 17 & 29.3 & 1.000 & $-\cdots$ & \\
\hline
\end{tabular}

*Model parameters: Pseudo- $R^{2}=0.432$; “-2 $\log$ Likelihood $=80.208$; Hosmer and Lemeshow $(\mathrm{p}=0.998)$; Pearson's Chi-square $\left(\mathrm{x}^{2}=9272\right.$; $P=0.099)$; Nagelkerke ( $\left.R^{2}: 0.460\right)$; Correct classification: $74.4 \%$ (Dizziness: no $=78.7 \%$; yes $=67.7 \%$ ).

The data from the studied sample evidenced that $33.7 \%$ of the elderly presented depressive symptoms. This prevalence is higher than that described by other authors, ${ }^{37}$ who report prevalence of $26.7 \%$ of depressive symptoms in a sample of elderly people residing in an urban zone. In turn, study reported depressive symptoms in $31 \%$ of the elderly evaluated, by also using the GDS scale in active elderly who were part of a conviviality group, i.e., a similar sample to the one evaluated in this study. Additionally, the cited authors verified that $4 \%$ of the evaluated elderly presented severe depressive symptoms, which was also similar to the obtained data. $^{38}$

Regarding Anterior Functional Reach results, the average obtained was $28.2 \pm 9.2 \mathrm{~cm}$. Hence, the biggest part of individuals evaluated presented low probability of falls. Results were higher than those observed by previous studies, ${ }^{39,40}$ and lower than those obtained by another study. ${ }^{41}$ Values found were similar to those observed in Brazil, ${ }^{42}$ which also evaluated a sample of adult and elderly people. The sample of elderly people in the age group between 70 and 87 years of age presented functional reach values between 29.75 (men) and 27.13 (women). Variations in the results of these studies can be explained through different factors, such as fall history, freight, strength, and flexibility of upper and lower limbs. ${ }^{42}$

This research verified a stronger presence of dizziness in the age group above 75 years ( $41.7 \%$ ), a significant association $(p=0.028)$ when compared with remaining age groups. Such a finding is similar to that of the research with 1,273 elderly between 60 and 96 years of age, which verified reports of dizziness in $23.6 \%$ of all elderly evaluated. In this study, $17.8 \%$ of them were under 80 and $31 \%$ were over 80 years old. ${ }^{30}$ Another longitudinal research with 620 elderly people verified that dizziness was a factor that depended on age, with prevalence of $27 \%$ in the elderly under 70 , and over $54 \%$ in the group with 90 years of age or more. Among the elderly that mentioned dizziness, $68.2 \%$ perceived this symptom daily or weekly. ${ }^{43}$ The bigger prevalence of dizziness in the age group above 75 years of age could be due to the generalized deterioration of health in older people ${ }^{44}$ or multifactor conditions, both medical and functional. ${ }^{43}$

It is worth mentioning that the presence of dizziness is directly related to the presence of falls in the elderly population; ${ }^{30}$ both conditions are considered geriatric syndromes that occur concomitantly to other harms to multiple systems of the body. ${ }^{5}$ This worsens with age. The elderly who suffer falls can have fractures as a consequence, which might require longer periods in bed. Such condition is responsible for $70 \%$ of deaths resulting from accidents in individuals over 75 years in age. ${ }^{45}$

Further to this, there was no significant difference when comparing the presence of dizziness complaints among the elderly who practiced physical exercise whith those who did not. These data were different from the expectations of the authors and the findings of Ruwer et $\mathrm{al}^{35}$ because, according to these authors, the complaint of dizziness is less prevalent in the elderly that practice physical exercise. Nevertheless, with the adjusted logistic regression, it is possible to verify that the individuals who do not practice physical exercise are 2.2 times more likely of feeling dizzy than physically active 
individuals are. This result confirms studies that compared elderly people with and without dizziness and observed that those without complaints of dizziness were engaged in physical activity. ${ }^{46}$ These authors also verified that there was a relation between dizziness and depression, which attest to the data from our study. The research verified a significant association between light to moderate depressive symptoms and 4.5-fold increase in the risk of feeling dizziness.

Regarding the Anterior Functional Reach Test, this research verified a significant association between the probability of falls and reports of dizziness. The elderly with medium probability of falling are four times more likely to feel dizziness than the elderly with low probability of falls, as described in another study. ${ }^{47}$

The studies indicate that active elderly people are less prone to depression than the sedentary elderly. ${ }^{19,48,49}$ Physical exercises help to reduce depression, aside from helping in its prevention. Physical activity relates to less frequent mood disorders and may even help release some neurotransmitters, such as noradrenalin and serotonin. ${ }^{50,51}$

Studies indicate that elderly people who practice regular physical activity mention less depressive symptoms than non-active or sedentary elderly people. Analysis of social skills, social support, life quality and depression of elderly people in an extension project, family contexts and asylums indicated that the depressive symptom was present in $0 \%$ of practicing elderly people compare to $30 \%$ of the elderly who did not participate in the project. In the asylum, in turn, this percentage increased $40 \%{ }^{52}$ In other study about the intensity and prevalence of depressive symptoms in elderly women participating in an extension project, it was verified an absence of depressive symptoms in $80.6 \%$ of the sample. ${ }^{53}$ Another study evaluated the effect of a program of aerobic physical exercise in the intensity of the ventilator threshold over depression and anxiety and life quality of healthy elderly people divided into a control and a experimental group. The elderly in the experimental group had a reduction in the scores of depression and anxiety and an increase in life quality, while in the control group no changes were observed. ${ }^{51}$

In the research on the freight of falling and its relation with balance and mobility tests, there was a moderate correlation. ${ }^{40}$ Authors state that balance and mobility enable the stability necessary to maintain a standing position, for instance. Therefore, maintaining adequate levels of such capabilities reduces the risk of falls, which are directly related to level of physical activity. The American College of Sports Medicine ${ }^{54}$ mentions that the level of physical activity is inversely related to the number of limitations in the elderly.

Brazilian authors analyzed the relation between health conditions, incidence of falls, and level of physical activity in 256 elderly people. Results indicated an association between the level of physical activity and the incidence of falls and health conditions. In other words, the more frequent the practice of physical activity the less the occurrence of falls. Muscular weakness, reduction in articular mobility, degraded synergy, programming mechanisms, and motor control difficulties are the variables present in low levels of physical activity, predisposing to falls in the elderly. ${ }^{55}$

\section{Conclusion}

The results of this study indicated the existence of an association between the practice of physical exercise, dizziness, probability of falls, and depressive symptoms in a group of non-institutionalized middle aged adults and elderly people, evidencing that physical activity is a beneficial factor for the aging population.

\section{References}

1 United Nations. The Millennium Development Goals Report. [Internet]. New York: 2011. Available at: http://www.un.org/millenniumgoals/pdf/(2011_E)\%20MDG\%20Report\%202011_Book\% 20LR.pdf. Accessed Jun 19, 2015.

2 Beard J, Biggs S, Bloom D, et al. Working Paper Series - Global Population Ageing: Peril or Promise? Program on the Global Demography of Aging. [Internet]. Geneva: 2012. Available at: http://cdn1.sph.harvard.edu/wp-content/uploads/sites/1288/

2013/10/PGDA_WP_89.pdf. Accessed Jun 19, 2015.

3 World Health Organization. Good health adds life to years. Global brief for world health day 2012. [Internet]. Geneva: 2012. Available at: http://whqlibdoc.who.int/hq/2012/WHO_DCO_WHD_2012.2_eng.pdf?ua=1. Accessed Jun 19, 2015.

4 Shumway-Cook A, Woollacott MH. Controle postural normal. In: Shumway-Cook A, Woollacott MH. Controle motor - teoria e aplicações práticas. Barueri: Manole; 2003:153-178

5 Tinetti ME, Williams CS, Gill TM. Dizziness among older adults: a possible geriatric syndrome. Ann Intern Med 2000;132(5): 337-344

6 Matsumura BA, Ambrose AF. Balance in the elderly. Clin Geriatr Med 2006;22(2):395-412, x

7 Rogério RS. Qualidade de vida em uma população de idosos com vestibulopatias atendidos no laboratório da UNIBAN Brasil [dissertation]. São Paulo: Universidade Bandeirante de São Paulo; 2010:53

8 Ganança MM, et al. Como diagnosticar e tratar a vertigem. RBM Rev Bras Med 2008;65:6-14

9 Caovilla HH, Ganança MM. A vertigem e sintomas associados. In: Ganança MM, Vieira RM, Caovilla HH, eds. Princípios de Otoneurologia. São Paulo: Atheneu; 1998:3-5

10 Ganança MM, Mezzalira R, Cruz OLM. Campanha nacional de prevenção a quedas de idosos dia 27 de setembro: dia de atendimento ao idoso com tontura. Rev Bras Otorrinolaringol (Engl Ed) 2008;74(2):162

11 Simocelli L, Bittar MS, Bottino MA, Bento RF. Perfil diagnóstico do idoso portador de desequilíbrio corporal: resultados preliminares. Rev Bras Otorrinolaringol (Engl Ed) 2003;69(6):772-777

12 Balaban CD, Jacob RG. Background and history of the interface between anxiety and vertigo. J Anxiety Disord 2001;15(1-2): 27-51

13 Ganança FF, Castro ASO, Branco FCC, Natour J. Interferência da tontura na qualidade de vida de pacientes com síndrome vestibular periférica. Rev Bras Otorrinolaringol (Engl Ed) 2004;70(1): 94-101

14 Paradela EMP, Lourenço RA, Veras RP. Validação da escala de depressão geriátrica em um ambulatório geral. Rev Saude Publica 2005;39(6):918-923

15 Batistoni SST. Depressão. In: Neri AL. Palavras-chave em gerontologia. Campinas: Alinea; 2005:59-61

16 Chatton A, Kayser B. Self-reported health, physical activity and socio-economic status of middle-aged and elderly participants to a 
popular road running race in Switzerland: better off than the general population? Swiss Med Wkly 2013;143:w13710

17 Fortes C, Mastroeni S, Sperati A, et al. Walking four times weekly for at least $15 \mathrm{~min}$ is associated with longevity in a cohort of very elderly people. Maturitas 2013;74(3):246-251

18 Stella F, Gobbi S, Corazza DJ, Costa JLR. Depressão no idoso: diagnóstico, tratamento e benefícios da atividade física. Motriz Rev Educ Fís 2002;8(3):91-98

19 Cheik NC, et al. Efeitos do exercício físico e da atividade física na depressão e ansiedade em indivíduos idosos. RBCM 2003;11(3): 45-52

20 Frontera WR, Dawson DM, Slovik DM. Exercício físico e reabilitação. Porto Alegre: Artmed; 2001

21 Vaz Garcia F. Disequilibrium and its management in elderly patients. Int Tinnitus J 2009;15(1):83-90

22 Walther LE, Rogowski M, Schaaf H, Hörmann K, Löhler J. Falls and dizziness in the elderly. Otolaryngol Pol 2010;64(6):354-357

23 Canário AC, Cabral PU, Spyrides MH, Giraldo PC, Eleutério J Jr, Gonçalves AK. The impact of physical activity on menopausal symptoms in middle-aged women. Int J Gynaecol Obstet 2012; 118(1):34-36

24 Almeida OP, Almeida SA. Confiabilidade da versão brasileira da escala de depressão em geriatria (GDS) versão reduzida. Arq Neuropsiquiatr 1999;57(2B)421-426

25 Duncan PW, Weiner DK, Chandler J, Studenski S. Functional reach: a new clinical measure of balance. J Gerontol 1990;45(6): M192-M197

26 Ministério da Saúde. Vigitel Brasil 2007: vigilância de fatores de risco e proteção para doenças crônicas por inquérito telefônico. [Internet]. Brasília; 2007. Available at: http://bvsms.saude.gov. br/bvs/publicacoes/vigitel_brasil_2007.pdf. Accessed Jun 19, 2015

27 Courseuil MW, Hallal PC, Courseuil H, Schneider I, D'orsi E. Safety for crime and physical activity among older adults: a populationbased study in Brazil. J Environ Public Health 2012;12(7):1-7

28 Pucci G, Reis RS, Rech CR, Hallal PC. Quality of life and physical activity among adults: population-based study in Brazilian adults. Qual Life Res 2012;21(9):1537-1543

29 Lin HW, Bhattacharyya N. Balance disorders in the elderly: epidemiology and functional impact. Laryngoscope 2012;122(8): 1858-1861

30 Olsson Möller U, Midlöv P, Kristensson J, Ekdahl C, Berglund J, Jakobsson U. Prevalence and predictors of falls and dizziness in people younger and older than 80 years of age-a longitudinal cohort study. Arch Gerontol Geriatr 2013;56(1):160-168

31 Menant JC, Wong A, Sturnieks DL, et al. Pain and anxiety mediate the relationship between dizziness and falls in older people. J Am Geriatr Soc 2013;61(3):423-428

32 Rosso AL, Eaton $\mathrm{CB}$, Wallace R, et al. Geriatric syndromes and incident disability in older women: results from the women's health initiative observational study. J Am Geriatr Soc 2013;61(3): 371-379

33 de Moraes SA, Soares WJS, Ferriolli E, Perracini MR. Prevalence and correlates of dizziness in community-dwelling older people: a cross sectional population based study. BMC Geriatr 2013;13:4

34 Caovilla HH, Ganança MM, Munhoz MSL, Silva MLG, Ganança FF. Presbivertigem, Presbiataxia, Presbizumbido e Presbiacusia. In: Silva MLF, Munhoz MSL, Ganança MM, Caovilla HH. eds. Quadros clínicos otoneurológicos mais comuns. São Paulo: Atheneu; 2000: 153-158

35 Ruwer SL, Rossi AG, Simon LF. Equilíbrio no idoso. Rev Bras Otorrinolaringol (Engl Ed) 2005;71(3):298-303
36 Soares EV. Reabilitação vestibular em idosos com desequilíbrio para marcha. Perspectivas Online 2007;1(3):88-100

37 da Silva EF, Paniz VMV, Laste G, Torres ILS. Prevalência de morbidades e sintomas em idosos: um estudo comparativo entre zonas rural e urbana. Cien Saude Colet 2013;18(4):1029-1040

38 Oliveira DAP, Gomes L, Oliveira RF. Prevalência de depressão em idosos que freqüentam centros de convivência. Rev Saude Publica 2006;40(4):734-736

39 Gai J, Gomes L, Nóbrega OT, Rodrigues MP. Fatores associados a quedas em mulheres idosas residentes na comunidade. AMB Rev Assoc Med Bras 2010;56(3):527-532

40 Lopes KT, Costa DF, Santos LF, Castro DP, Bastone AC. Prevalência do medo de cair em uma população de idosos da comunidade e sua correlação com mobilidade, equilíbrio dinâmico, risco e histórico de quedas. Rev Bras Fisioter 2009;13(2):223-229

41 Ramos BMB. Influências de um programa de atividade física no controle do equilíbrio em idosos. [dissertation]. São Paulo: Universidade de São Paulo; 2006

42 Silveira KRM, Matas SLA, Perracini MR. Avaliação do desempenho dos testes functional reach and lateral reach em uma amostra populacional brasileira. Rev Bras Fisioter 2006;10(4):381-386

43 Gassmann KG, Rupprecht R; IZG Study Group. Dizziness in an older community dwelling population: a multifactorial syndrome. J Nutr Health Aging 2009;13(3):278-282

44 Grundstrom AC, Guse CE, Layde PM. Risk factors for falls and fallrelated injuries in adults 85 years of age and older. Arch Gerontol Geriatr 2012;54(3):421-428

45 Gazzola JM, Perracini MR, Ganança MM, Ganança FF. Fatores associados ao equilíbrio funcional em idosos com disfunção vestibular crônica. Rev Bras Otorrinolaringol (Engl Ed) 2006; 72(5):683-690

46 Ekwall A, Lindberg A, Magnusson M. Dizzy - why not take a walk? Low level physical activity improves quality of life among elderly with dizziness. Gerontology 2009;55(6):652-659

47 Teixeira AR, et al. Associação entre tonturas, quedas e teste do alcance funcional em idosos da comunidade. Estud Interdiscip Envelhec 2011;16(suppl.):461-472

48 Benedetti TRB, Borges LJ, Petroski EL, Gonçalves LHT. Atividade física e estado de saúde mental de idosos. Rev Saude Publica 2008; 42(2):302-307

49 Sguizzatto GT, Garcez-Leme LE, Casimiro L. Evaluation of the quality of life among elderly female athletes. Sao Paulo Med J 2006;124(5):304-305

50 Moraes H, Deslandes A, Ferreira C, Pompeu FAMS, Ribeiro P, Laks J. O exercício físico no tratamento da depressão em idosos: revisão sistemática. Rev Psiquiatr Rio Gd Sul 2007;29(1):70-79

51 Antunes HKM, Stella SG, Santos RF, Bueno OFA, de Mello MT. Depression, anxiety and quality of life scores in seniors after an endurance exercise program. Rev Bras Psiquiatr 2005;27(4): 266-271

52 Carneiro RS, Falcone E, Clarck C, Del Prette Z, Del Prete A. Qualidade de vida, apoio social e depressão em idosos: relação com habilidades sociais. Psicol Reflex Crit 2007;20(2):229-237

53 Irigaray TQ Schneider RH. Prevalência de depressão em idosas participantes da Universidade para a Terceira Idade. Rev Psiquiatr Rio Gd Sul 2007;29(1):19-27

54 American College of Sports Medicine. American College of Sports Medicine Position Stand. Exercise and physical activity for older adults. Med Sci Sports Exerc 1998;30(6):992-1008

55 Mazo G, Liposcki DB, Ananda C, Prevê D. Condições de saúde, incidência de quedas e nível de atividade física de idosos. Rev Bras Fisioter 2007;11(6):437-442 